\title{
Adding an extra tire to the standard axle to reduce pavement damage due to overload
}

\author{
Adlicionar um pneu extra ao eixo padrão para reduzir os danos ao pavimento devido à sobrecarga \\ Agregar una llanta adicional al eje estándar para reducir el daño al pavimento debido a la sobrecarga
}

Received: 01/10/2021 | Reviewed: 01/12/2021 | Accept: 01/16/2021 | Published: 01/19/2021

Paulo Boulos Filho

ORCID: https://orcid.org/0000-0003-1101-5374

Universidade Paulista, Brazil

E-mail:pa.boulos@hotmail.com

Irenilza de Alencar Nääs

ORCID: https://orcid.org/0000-0003-0663-9377

Universidade Paulista, Brazil

E-mail: irenilza.naas@docente.unip.br

Raquel Baracat Tosi Rodrigues da Silva

ORCID: https://orcid.org/0000-0001-7184-8162

Universidade Paulista, Brazil

E-mail: raquelbaracat@gmail.com

\begin{abstract}
The present work grants a study of technical development under a differentiated aspect where an extra tire was added to the standard double axle recommended by the Brazilian traffic calculation norms. The number $\mathrm{N}$ generated a triple axle, and a comparative study was made relating the balance load standardized in Brazilian balance laws for each type of axis and the damage generated on the pavement, measuring the results on a pavement chosen as a model, usually used on Brazilian highways. We verified through computer software, which uses the methodology of the theory of finite elements, supervised by the inspection bodies of the National Department of Transport infrastructure, proving if a larger amount of cargo generates the same damage to the pavement without jeopardizing its useful life, which was initially designed to last ten years.
\end{abstract}

Keywords: Development; Technical; Transportation; Axle; Triple.

\section{Resumo}

O presente trabalho apresenta um estudo de desenvolvimento técnico sob um aspecto diferenciado onde foi adicionado um pneu extra ao eixo duplo padrão preconizado pelas normas brasileiras de cálculo de tráfego. O número N, gerou um eixo de rodagem tripla e foi feito um estudo comparativo relacionando a carga de balança normatizada nas leis brasileiras de balança por cada tipo de eixo e o dano gerado no pavimento medindo os resultados em um pavimento eleito como modelo, usualmente utilizado em rodovias brasileiras. Foi verificado, através de software computacional, que utiliza a metodologia da teoria dos elementos finitos, preconizado pelos orgãos fiscalizadores do Departamento Nacional de infraestrutura de Transportes, averiguando se uma quantidade de carga maior gera o mesmo dano ao pavimento, sem prejudicar a sua vida útil, que inicialmente foi projetado para durar dez anos.

Palavras-chave: Desenvolvimento; Técnico; Transporte; Eixo; Tripla.

\section{Resumen}

Este trabajo presenta un estudio de desarrollo técnico bajo un aspecto diferente donde se agregó un neumático extra al doble eje estándar recomendado por las normas de cálculo de tráfico brasileño, es decir, el número N, generando un eje de triple carro y se realizó un estudio comparativo relativo la carga de balance estandarizada en las leyes de balance brasileñas para cada tipo de eje y el daño generado en el pavimento, midiendo los resultados en un pavimento elegido como modelo, generalmente utilizado en las carreteras brasileñas, verificando a través de software de computadora, que utiliza la metodología de la teoría de elementos finitos, supervisados por los órganos de inspección de la infraestructura de la Secretaría de Transporte de la Nación, verificando si una mayor cantidad de carga genera el mismo daño en el pavimento, sin comprometer su vida útil, que inicialmente fue diseñada para durar diez años.

Palabras clave: Desarrollo; Técnico; Transporte; Eje; Triple.

\section{Introduction}

The concept of road pavement means a structure constituted on is a structure built on the surface obtained by earthmoving services with the primary function of providing the user with safety and comfort, achieved with the maximum 
quality and minimum cost (Santana, 1993; Pais et al., 2019). Souza (1981) states that pavement is a structure built through layers of various materials of different characteristics of strength and deformability. This structure presents a high degree of complexity concerning the calculation of stresses and deformations. A highway pavement is a superstructure consisting of a system of layers of finite thicknesses, based on a semi-space considered theoretically as infinite (the infrastructure or foundation ground called a subgrade; IPR-DNIT, 2006). According to NBR (1982), the pavement is a structure built after earthworks, intended to resist and distribute to the subgrade the vertical stresses produced by traffic. Moreover, the design needs to attend to the account load capacity, bear comfort, and interact between vehicle and pavement. Structurally, layers of coating, base, sub-base and, reinforcement of subgrade and subgrade, considering from the top to the natural terrain.

Road modal is the primary means of transport of cargo in Brazil. Throughout the 1990s and 2000s, this modal accounted for more than $60 \%$ of the total freight transported in the country (IPEA, 2020). Excluding the transportation of iron that occurs by railway, highways account for more than $70 \%$ of general cargos. During the '50s, road modal accounted for $38 \%$ of national cargo transportation (BNDES, 2008). In the '70s, highways were prioritized, seeking to stimulate the manufacturing industry through the automotive industry. Since then, the Brazilian transport matrix has remained unbalanced with investments for this type of modal. This modal's significant dependence on the transport of Brazilian cargo emphasized when compared to other countries with continental dimensions. In the U.S.A., this modal is $26 \%$, while in Australia, it is $24 \%$, and in China, only $8 \%$ (Bartholomeu, 2006).

According to the National Transport Confederation (CNT, 2020), the Brazilian road network consists of $1.3105 \mathrm{~km}$ of unpaved highways and $0.2105 \mathrm{~km}$ of paved streets of $1.5105 \mathrm{~km}$, representing one of the world's largest road networks. Despite its entire length, it observed that only about $12.4 \%$ of the road paved. A study conducted by The Institute of Applied Economic Research (IPEA, 2020) found that it takes 183.5 billion reais to solve the pavement conservation issues and boost the road sector, increasing its efficiency and impact on the country's economy. Road paving can be costly, including restoration and maintenance, in addition to providing the function of allowing adequate trafficability to users with comfort and safety, resisting traffic actions, and distributing efforts to the underlying layers of the pavement.

One of the main factors for determining the pavement's life is the type and volume of traffic to which it will expose throughout the life span and project. Therefore, studies are needed to focus on a better traffic contribution on pavement dimensioning and lifespan (Medina \& Motta, 2005). A software was developed to verify the project's feasibility durability, aiming to measure factors for determining pavement sizing combining current traffic, projected traffic, and its consequences of use, mainly through commercial loads, in the pavement's fatigue structure. The standards are agreed upon and accepted by the National Department of Transport Infrastructure (DNIT). According to the DER (2006), the state representatives established a standard single axle or double wheels of $80 \mathrm{kN}$ and the contact pressure tire/pavement of $0.56 \mathrm{MPa}$. They assume a diversity of variables (ambient temperature, differences in loads transported, the absence of automatic pressure calibration in the vehicle. The negligence of the driver with the tire calibration and the balance load allowed). Other factors such as tire quality and leaks, we can indicate through these variations in the tire pressure applied to the pavement the differences resulting in the structure's fatigue through a study where the loads change in the mechanistic analysis program verifying the behavior of the design.

According to Lin et al. (2016), the dynamic module is recognized as an objective and sensitive property of the material for designing and evaluating pavement systems to accurately measure the in situ elastic moduli (Eq. 1). For evaluating the nondestructive quality of asphalt pavements, field measurements of density (q) via the electromagnetic meter and shear wave velocity (Vs) via surface wave test were examined by four projects covering a variety of mixtures and traffic loads. The Finite Elements model successfully captures each layer's constitutive model characteristics and the interaction between different layers and boundary conditions. With the proper development of Finite Element models, further research carried out for back analysis of layer modules using database combination from direct FE analysis and artificial intelligence techniques. 


$$
E=2(1+m) q V s 2
$$

Kim et al. (2018) observed that the effect of different configurations of regular contact stresses on the performance of grooves of soft and rigid and Crushed Graduated Gravel layers in the Finite Elements model, based on a real structure of the generated pavement and the asphaltic concrete layer simulated as a viscoplastic viscoelastic material system. Therefore, the present study had the purpose of verifying the pavement of Brazilian road projects, with pre-established and constant dimensions, varying the number of tires used, and we verified the pressure applied to the pavement, used by the standard methodology, and confirmed the effect on the layers through the fatigue equations standardized by the DNIT (2006).

\section{Material and Methods}

For meeting the objective, we used the deduction method with qualitative and quantitative approaches (Pereira et al., 2018). The standards agreed and accepted by the projects of the National Department of Transport Infrastructure-DNIT and its state representatives according to the Paving Manual - IPR - 719 (2006) or IP-DE-P00/001-Paving Projects of DER/SP, established the standard single axle or double wheels of $80 \mathrm{kN}$ and the contact pressure tire/pavement of $0.56 \mathrm{MPa}$. The structures of a pavement project were validated through computational software that uses finite element theory. For this study, the Software Elsym5 -Elastic System included, and the values of the N number validated by fatigue equations accepted by DER/SP and DNIT.

\subsection{Methods of calculating the $N$ number and its variables}

The number "N" is calculated using Equation 1.

$$
N=365 \times P \times V D M \times F V \times F R \times D \times d
$$

where, $\mathrm{N}=$ number of requests equivalent to the default axis; $\mathrm{P}=$ project period; $\mathrm{VDM}=$ average daily traffic volume; $\mathrm{FV}=$ vehicle factor; $F R=$ regional climate factor; $D=$ percentage of commercial vehicles in the most requested range; $d=$ percentage of vehicles per direction.

Defined the project period of 10 years, according to the guidelines of the Department of Highways of the State of São Paulo (DER/SP) the determination of the $\mathrm{N}$ number consists, initially, in the definition of the traffic volumes of each type of vehicle and its projection of growth.

The second stage of calculation is the vehicle factor (VF) definition, which allows the determination of the number of axles equivalent to the standard axle from the volume of vehicles with a specific configuration of axles and loads that travel during the design period. The vehicle factor is calculated from Equation 2.

$$
F V=F E \times F C
$$

where $\mathrm{FE}=$ axis factor; $\mathrm{HR}=$ load equivalence factor.

The maximum loads by axle type defined in the Balance Law and the Brazilian Traffic Code (Law No. 9.053.de 23/09/1997 - resolution no. 12 of 02/06/1998) correspond to 6.0 tf on the single front axle, and 10.0 TF, 17.0 TF, and 25.5 TF for single axles, double tandem, and triple tandem rear, respectively.

The factors of equivalence to the standard load of $8.2 \mathrm{tf}$ are determined analytically, through two calculation methods, the United States Army Corps of Engineers (USACE) and the American Association of State Highway and Transportation Officials (AASHTO, 1972), the first recommended by der/sp and the second for mechanistic evaluation purposes. The procedure of dimensioning the Department of Highways of the State of São Paulo considered variations in the humidity of the pavement's 
constituent materials during the various seasons (which translates into variations in the materials' support capacity). The equivalent number of requests of the standard axis (or traffic parameter) "N" is multiplied by a coefficient "FR" called Regional Factor, which, in the AASHTO (1993) experimental track, ranged from 0.2 (occasions when low moisture content prevails) to 5.0 (occasions when the materials are practically saturated).

In Brazil, there are no experimental elements for such determination, but according to the recommendations of the Department of Highways of the State of São Paulo, one can adopt: FR = 1.0

\subsection{Verification of pavement structures through the theory of elasticity}

Vehicle loads generate stresses and deformations inside the pavement structure. These stresses and deformations are a function of the magnitude of the loading, the resilient modules and thicknesses of the pavement constituent layers, and the subgrade support capacity. Therefore, the displacements and active deformations that originate inside the loaded pavement were determined for later comparison with the values of displacements and permissible deformations that are a function of the type of material used in the pavement structure. To determine the internal efforts requesting, deformations, and displacements of the flexible layer structure, the Elsym5 (ElasticLayered System)computational program was used, which considers constant elastic characteristics for each layer of the pavement structure. The parameters used for the calculation were:

Standard $80 \mathrm{kN}$ single shaft load, represented by 4 x $20 \mathrm{kN}$;

Tire/layer contact pressure of $5.6 \mathrm{kgf} / \mathrm{cm}^{2}$;

ASPHALT Resilience Module (Coating) of $35.000 \mathrm{kgf} / \mathrm{cm}^{2}$;

Simple Graded Gravel resilience module of $3.000 \mathrm{kgf} / \mathrm{cm}^{2}$;

Macadam resilience module of $2.500 \mathrm{kgf} / \mathrm{cm}^{2}$;

$700 \mathrm{kgf} / \mathrm{cm} 2$ subgrade resilience module for $\mathrm{CBR}=7 \%$

where ASPHALT $=$ Hot Machined Bituminous Concrete; $\mathrm{kN}=$ kilo Newton; $\mathrm{CBR}=$ California Bearing Ratio $; \mathrm{kgf} / \mathrm{cm}^{2}=$ kilogram strength per square centimetre. The displacements and internal deformations of the structure were determined in its critical locations, i.e., at the top of the asphaltic concrete layer (vertical displacement), in the lower fiber of the asphaltic concrete layer (horizontal tensile deformation), and at the top of the subgrade (vertical compression deformation). Fatigue equations 3 , 4, and 5 were used to determine permissible efforts. Vertical displacement on the layer surface - deflection - D0 $10^{-2}$ (mm). PRO 11 DNER Model (DNER, 1979).

$$
\log D_{0_{a d m}}=3,01-0,176 \times \log N
$$

The horizontal tensile deformation in the coating's bottom fiber is $\varepsilon t 10^{-4}(\mathrm{~cm} / \mathrm{cm})$, FHWA (Federal Highway Association, AASHTO, 1972).

$$
N=1,09 \times 10^{-6} \times\left(\frac{1}{\varepsilon_{\text {tadm }}}\right)^{3,512}
$$

Vertical compression deformation at the top of the subgrade layer is $\varepsilon \mathrm{V} 10^{-4}(\mathrm{~cm} / \mathrm{cm})$, (Dormon \& Metcalf, 1965).

$$
N=6,069 \times 10^{-10} \times\left(\frac{1}{\varepsilon_{v_{a d m}}}\right)^{4,762}
$$


The values obtained by the software used in the fatigue equations represented above for each layer, and the $\mathrm{N}$ number of requests from the common axis for the design period found.

In the present study, aiming to optimize freight and load distribution on the pavement, we consider another tire added to the standard axle and using the existing parameters. A load simulation was rotated and verified through the finite element theory and fatigue equations recommended by DER/SP and DNIT, which are the results at the top of the layer, in its useful life and load increment possibilities.

\section{Results}

Tables 1 and 2 show the output data applied to the fatigue equations. The results compared to the values obtained the standard axis considered for the 10-year project according to Brazilian standards' requirements. The amount was compatible with initial overloads of 5\% added, and the program rerun until the 50\% for comparison purposes only. Checking the Overall Results Standard Axle table for deflection in the ASPHALT layer, where the DER/SP PRO-11 equation used equation 3, the value of N considered for the standard axis of $8.2 \mathrm{t}$, of 7,55 x 107 was found in the Triple Axle table when adding the amount of $15 \%$ load. For the ASPHALT layer's traction, the Federal Highway Association equation used the original $\mathrm{N}$ for the standard axis was found only between 40 and $45 \%$ of load increase. For the deflection at the top of the subgrade, where the Shell equation(1978) and Dormon \& Metcalf (1965) used, the original N for the standard axis found only between 35 and $40 \%$ of load increase.

In the first reading of the pavement, using the triple tire, there is a tolerance up to $15 \%$ of overload; for the second reading, a tolerance is between 40 and $45 \%$ of overload, and in the last layer in the subgrade, the tolerance is between 35 and $40 \%$ overload more than initially projected with double running for ten years of design.

Table 1. Overall Results using standard axle.

\begin{tabular}{|c|c|c|c|c|c|c|c|c|c|c|c|c|c|c|}
\hline $\begin{array}{l}\text { Overload } \\
\qquad \%)\end{array}$ & $\begin{array}{c}\text { Total } \\
\text { Weight } \\
\text { Axle (kgf) }\end{array}$ & $\begin{array}{l}\text { Total } \\
\text { Weight } \\
\text { Wheel } \\
(\mathrm{kgf})\end{array}$ & $\begin{array}{c}\text { Deflexion } \\
\left(\times 10^{-}\right. \\
\left.{ }^{2} \mathrm{~mm}\right)\end{array}$ & $\begin{array}{l}\text { Deflexion } \\
\text { Nadm }\end{array}$ & $\begin{array}{l}\text { Var. } 10 \text { year Life } \\
\text { Extension } \\
\text { (\% Ref. ESRD 8,2tf) }\end{array}$ & $\begin{array}{c}\text { Damage } \\
(1 / 10 \text { year } \\
\text { var. })\end{array}$ & $\begin{array}{c}\mathrm{ch} \\
\left(\mathrm{x} 10^{-}\right. \\
{ }^{\mathrm{cm} / \mathrm{cm})}\end{array}$ & $\begin{array}{l}\mathrm{ch} \\
\mathrm{N}_{\mathrm{adm}}\end{array}$ & $\begin{array}{l}\text { Var. } 10 \text { year Life } \\
\text { Extension } \\
\text { (\% Ref. ESRD 8,2tf) }\end{array}$ & $\begin{array}{c}\text { Damage } \\
(1 / 10 \text { year } \\
\text { var.) }\end{array}$ & $\begin{array}{c}\varepsilon V \\
\left(\times 10^{-}\right. \\
\left.{ }^{4} \mathrm{~cm} / \mathrm{cm}\right)\end{array}$ & $\begin{array}{l}\varepsilon \mathrm{vV} \\
\mathrm{Nadm}^{2}\end{array}$ & $\begin{array}{l}\text { Var. } 10 \text { year Life } \\
\text { Extension } \\
\text { (\% Ref. ESRD 8,2tf) }\end{array}$ & $\begin{array}{c}\text { Damage } \\
(1 / 10 \text { year } \\
\text { var. })\end{array}$ \\
\hline 0 & 8.200 & $2.050,00$ & 42 & $7,55 \mathrm{E}+07$ & 1,00 & 1,00 & 2,137 & $8,47 E+06$ & 1,00 & 1,00 & 2,898 & $4,27 E+07$ & 1,00 & 1,00 \\
\hline 5 & 8.610 & $2.152,50$ & 44 & $5,80 \mathrm{E}+07$ & 0,77 & 1,30 & 2,224 & $7,36 \mathrm{E}+06$ & 0,87 & 1,15 & 3,039 & $3,41 \mathrm{E}+07$ & 0,80 & 1,25 \\
\hline 10 & 9.020 & $2.255,00$ & 46 & $4,50 E+07$ & 0,60 & 1,68 & 2,309 & $6,45 E+06$ & 0,76 & 1,31 & 3,180 & $2,75 E+07$ & 0,64 & 1,56 \\
\hline 15 & 9.430 & $2.357,50$ & 48 & $3,54 \mathrm{E}+07$ & 0,47 & 2,14 & 2,393 & $5,69 \mathrm{E}+06$ & 0,67 & 1,49 & 3,321 & $2,23 E+07$ & 0,52 & 1,91 \\
\hline 20 & 9.840 & $2.460,00$ & 51 & $2,51 E+07$ & 0,33 & 3,01 & 2,474 & $5,07 E+06$ & 0,60 & 1,67 & 3,461 & $1,83 \mathrm{E}+07$ & 0,43 & 2,33 \\
\hline 25 & 10.250 & $2.562,50$ & 53 & $2,01 E+07$ & 0,27 & 3,75 & 2,554 & $4,53 E+06$ & 0,53 & 1,87 & 3,600 & $1,52 \mathrm{E}+07$ & 0,36 & 2,81 \\
\hline 30 & 10.660 & $2.665,00$ & 55 & $1,63 E+07$ & 0,22 & 4,63 & 2,632 & $4,08 E+06$ & 0,48 & 2,08 & 3,740 & $1,27 E+07$ & 0,30 & 3,37 \\
\hline 35 & 11.070 & $2.767,50$ & 57 & $1,33 \mathrm{E}+07$ & 0,18 & 5,67 & 2,708 & $3,69 \mathrm{E}+06$ & 0,44 & 2,30 & 3,879 & $1,07 E+07$ & 0,25 & 4,01 \\
\hline 40 & 11.480 & $2.870,00$ & 59 & $1,10 E+07$ & 0,14 & 6,90 & 2,782 & $3,35 E+06$ & 0,40 & 2,53 & 4,018 & $9,01 E+06$ & 0,21 & 4,74 \\
\hline 45 & 11.890 & $2.972,50$ & 61 & $9,06 E+06$ & 0,12 & 8,34 & 2,854 & $3,07 E+06$ & 0,36 & 2,76 & 4,156 & $7,67 E+06$ & 0,18 & 5,57 \\
\hline 50 & 12.300 & $3.075,00$ & 63 & $7,54 E+06$ & 0,10 & 10,01 & 2,924 & $2,82 E+06$ & 0,33 & 3,01 & 4,294 & $6,57 E+06$ & 0,15 & 6,50 \\
\hline
\end{tabular}

Source: Authors. 
Table 2. Overall Results using a Triple wheel axle.

\begin{tabular}{|c|c|c|c|c|c|c|c|c|c|c|c|c|c|c|}
\hline $\begin{array}{l}\text { Overload } \\
(\%)\end{array}$ & $\begin{array}{c}\text { Total } \\
\text { Weight } \\
\text { Axle (kgf) }\end{array}$ & $\begin{array}{c}\text { Total } \\
\text { Weight } \\
\text { Wheel (kgf) }\end{array}$ & $\begin{array}{c}\text { Deflexion } \\
(\times 10-2 \mathrm{~mm})\end{array}$ & $\begin{array}{l}\text { Deflexion } \\
\text { Nadm }\end{array}$ & $\begin{array}{l}\text { Var. } 10 \text { year } \\
\text { Life Extension } \\
\text { (\% Ref. ESRD } \\
8,2 t f)\end{array}$ & $\begin{array}{c}\text { Damage } \\
\text { (1/10 year } \\
\text { var.) }\end{array}$ & $\begin{array}{c}\text { Eh } \\
(\times 10- \\
4 \mathrm{~cm} / \mathrm{cm})\end{array}$ & $\begin{array}{c}\text { Eh } \\
\text { Nadm }\end{array}$ & $\begin{array}{l}\text { Var. } 10 \text { year } \\
\text { Life Extension } \\
\text { (\% Ref. ESRD } \\
8,2 t f)\end{array}$ & $\begin{array}{c}\text { Damage } \\
\text { (1/1/10 year } \\
\text { var.) }\end{array}$ & $\begin{array}{c}\varepsilon_{\mathrm{v}} \\
(\times 10- \\
4 \mathrm{~cm} / \mathrm{cm})\end{array}$ & $\underset{\mathrm{Nadm}}{\varepsilon_{\mathrm{v}}}$ & $\begin{array}{l}\text { Var. } 10 \text { year } \\
\text { Life Extension } \\
\text { (\% Ref. ESRD } \\
8,2 \text { ff) }\end{array}$ & $\begin{array}{c}\text { Damage } \\
\text { (1/10 year } \\
\text { var.) }\end{array}$ \\
\hline 0 & 8.200 & $1.366,67$ & 36 & $1,81 E+08$ & 2,40 & 0,42 & 1,708 & $1,86 \mathrm{E}+07$ & 2,20 & 0,46 & 2,124 & $1,88 \mathrm{E}+08$ & 4,39 & 0,23 \\
\hline 5 & 8.610 & $1.435,00$ & 38 & $1,33 E+08$ & 1,77 & 0,57 & 1,760 & $1,67 E+07$ & 1,98 & 0,51 & 2,228 & $1,49 \mathrm{E}+08$ & 3,50 & 0,29 \\
\hline 10 & 9.020 & $1.503,33$ & 40 & $9,97 E+07$ & 1,32 & 0,76 & 1,811 & $1,52 E+07$ & 1,79 & 0,56 & 2,332 & $1,20 E+08$ & 2,81 & 0,36 \\
\hline 15 & 9.430 & $1.571,67$ & 42 & $7,55 E+07$ & 1,00 & 1,00 & 1,861 & $1,38 \mathrm{E}+07$ & 1,63 & 0,62 & 2,436 & $9,77 E+07$ & 2,29 & 0,44 \\
\hline 20 & 9.840 & $1.640,00$ & 43 & $6,61 E+07$ & 0,87 & 1,14 & 1,909 & $1,26 E+07$ & 1,49 & 0,67 & 2,540 & $8,01 E+07$ & 1,87 & 0,53 \\
\hline 25 & 10.250 & $1.708,33$ & 45 & $5,10 E+07$ & 0,68 & 1,48 & 1,956 & $1,16 \mathrm{E}+07$ & 1,36 & 0,73 & 2,644 & $6,61 \mathrm{E}+07$ & 1,55 & 0,65 \\
\hline 30 & 10.660 & $1.776,67$ & 47 & $3,99 E+07$ & 0,53 & 1,89 & 2,001 & $1,07 E+07$ & 1,26 & 0,79 & 2,748 & $5,50 E+07$ & 1,29 & 0,78 \\
\hline 35 & 11.070 & $1.845,00$ & 48 & $3,54 E+07$ & 0,47 & 2,14 & 2,046 & $9,87 E+06$ & 1,17 & 0,86 & 2,852 & $4,61 E+07$ & 1,08 & 0,93 \\
\hline 40 & 11.480 & $1.913,33$ & 50 & $2,80 E+07$ & 0,37 & 2,69 & 2,089 & $9,17 E+06$ & 1,08 & 0,92 & 2,956 & $3,89 \mathrm{E}+07$ & 0,91 & 1,10 \\
\hline 45 & 11.890 & $1.981,67$ & 52 & $2,24 E+07$ & 0,30 & 3,37 & 2,131 & $8,56 \mathrm{E}+06$ & 1,01 & 0,99 & 3,060 & $3,30 E+07$ & 0,77 & 1,30 \\
\hline 50 & 12.300 & $2.050,00$ & 54 & $1,81 E+07$ & 0,24 & 4,17 & 2,172 & $8,00 E+06$ & 0,94 & 1,06 & 3,164 & $2,81 \mathrm{E}+07$ & 0,66 & 1,52 \\
\hline
\end{tabular}

Source: Authors.

In the first column, Tables 1 and 2 represent the percentage of load increased concerning the standard axis of $8200 \mathrm{~kg}$ represented in the second column. In the third column of Table 1, column two's value is divided by tires resulting in $2050 \mathrm{~kg}$ for each, whereas in Table 2, the value of the standard axle was divided by 6 because a wheel was added on each side of the standard axle double.

Deflection is the deformation in the pavement's top layer when the Elsym5 software reads the axle load's tension. Columns $\varepsilon$ and $\varepsilon v$ show the readings of the Elsym5 software for the tensile stress in the bottom layer of the CBUQ, and the deformation is shown at the top of the subgrade, respectively. The columns of variation in useful life represent a comparison to the 10-year life of the initial project, always being the standard axis considered zero variation and being compared to the load increase and triple rollover in Table 2. Finally, in the Damage column, 1 divided by the previous column's damage was shown to elucidate the variation.

Figures 1 through 4 present the comparison of the damage to the service life when using dual and triple axle loads. 
Figure 1. Comparison of damage to the service life (deflection) $v s$. overload for single axle dual tires and single axle triple tires due to standard axle load.

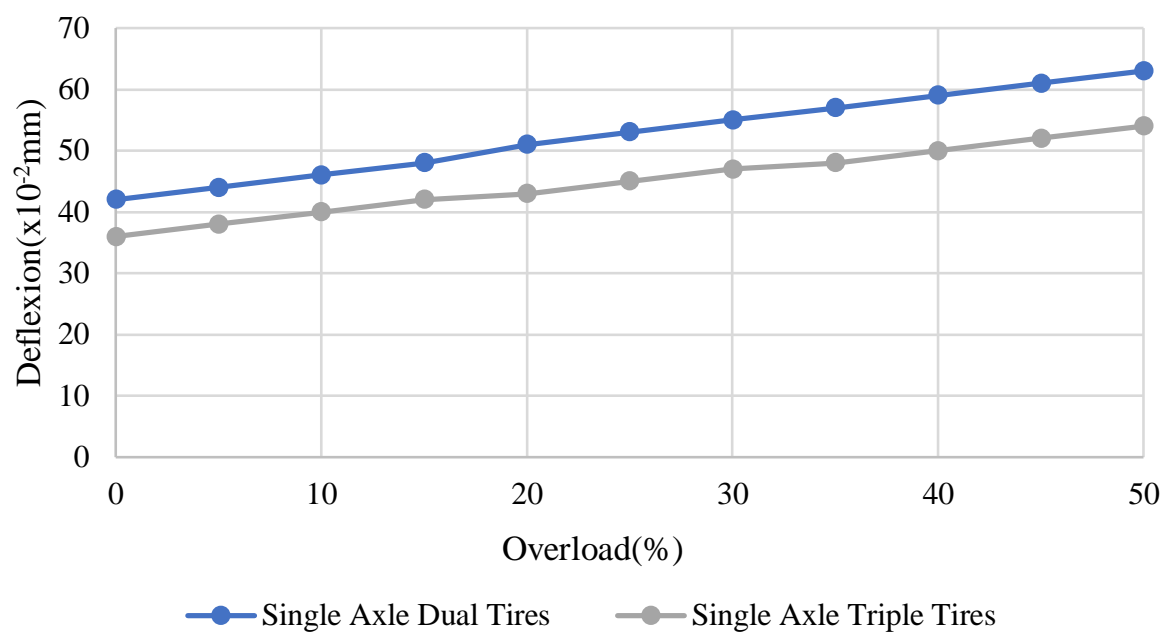

Source: Authors.

The graphs presented through values calculated by the theory of finite elements in the Elsym5 Software, recommended by the National Department of Transport Infrastructure, verified the common axis's balance load for the Brazilian legislation. These results showed an increase of $43.22 \%$ number N, generating the same damage to the project's pavement. Additionally, we can verify, as an example, that the triple axle accepts 15\% more overhead at the top of the asphalt layer to generate the same damage to the pavement in 10 years when compared to the standard double axle of design.

Figure 2. Comparison of damage to the service life (deflexion) vs. overload for single axle dual tires and single axle triple tires due to Brazil legal axle load.

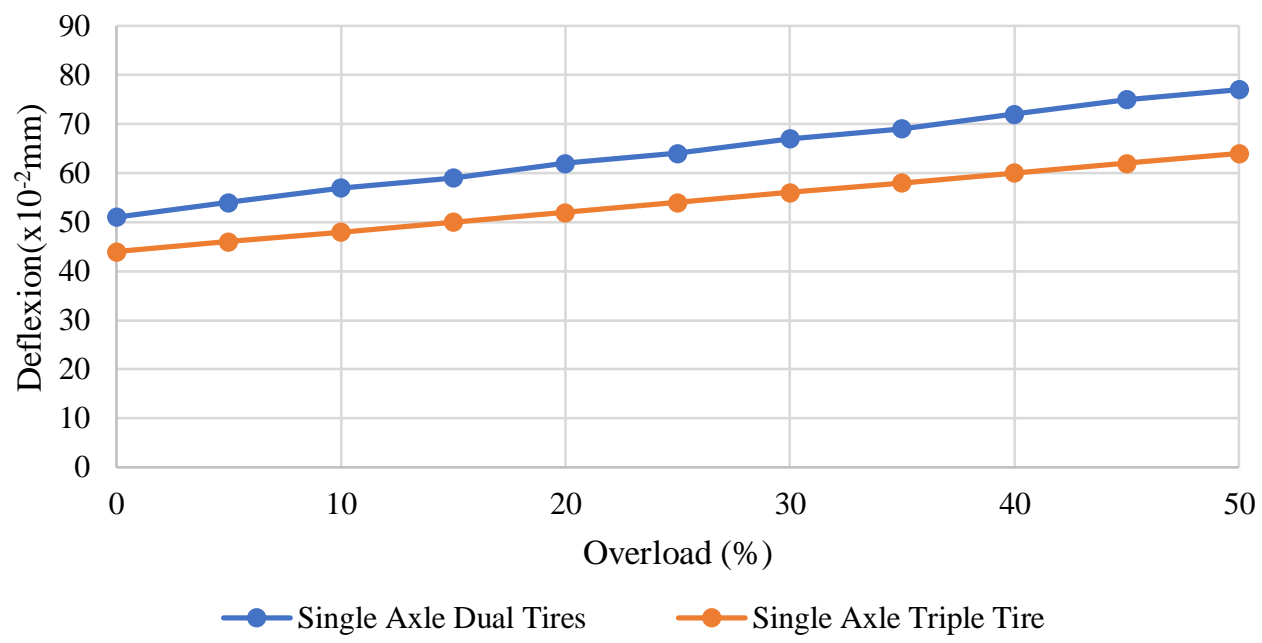

Source: Authors. 
Figure 3. Comparison of damage to the service life (N number) vs. overload for single axle dual tires and single axle triple tires due to standard axle load.

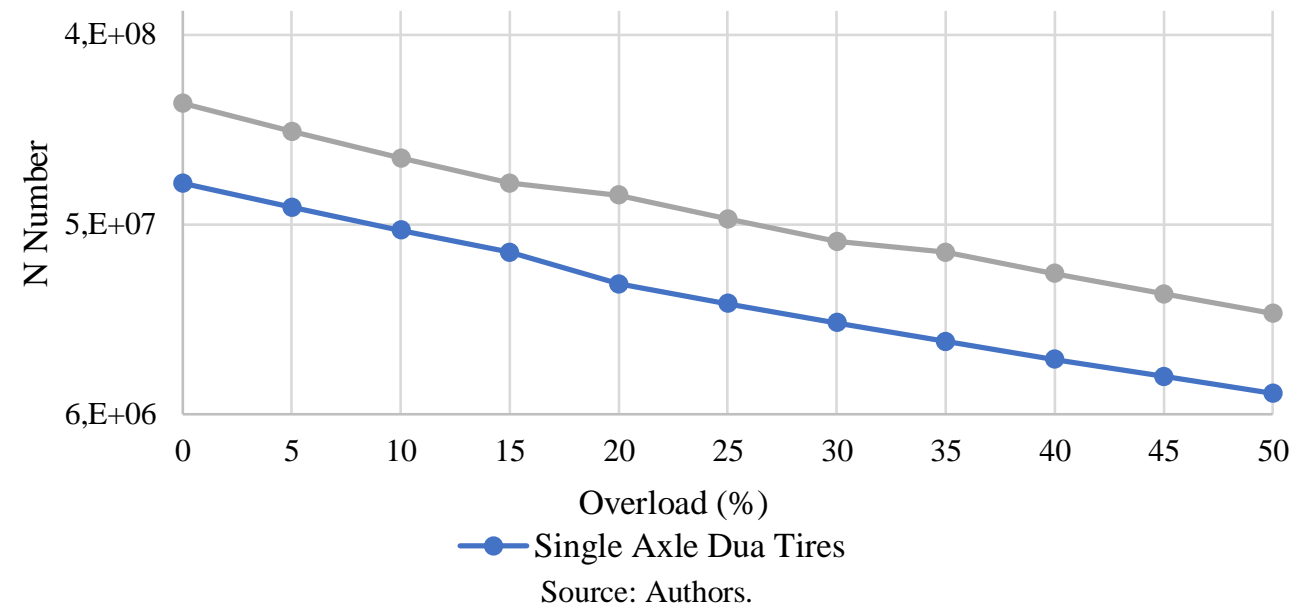

Figure 4. Comparison of the damage to the service life ( $\mathrm{N}$ number) vs. overload for single axle dual tires and single axle triple tires due to Brazil legal axle load.

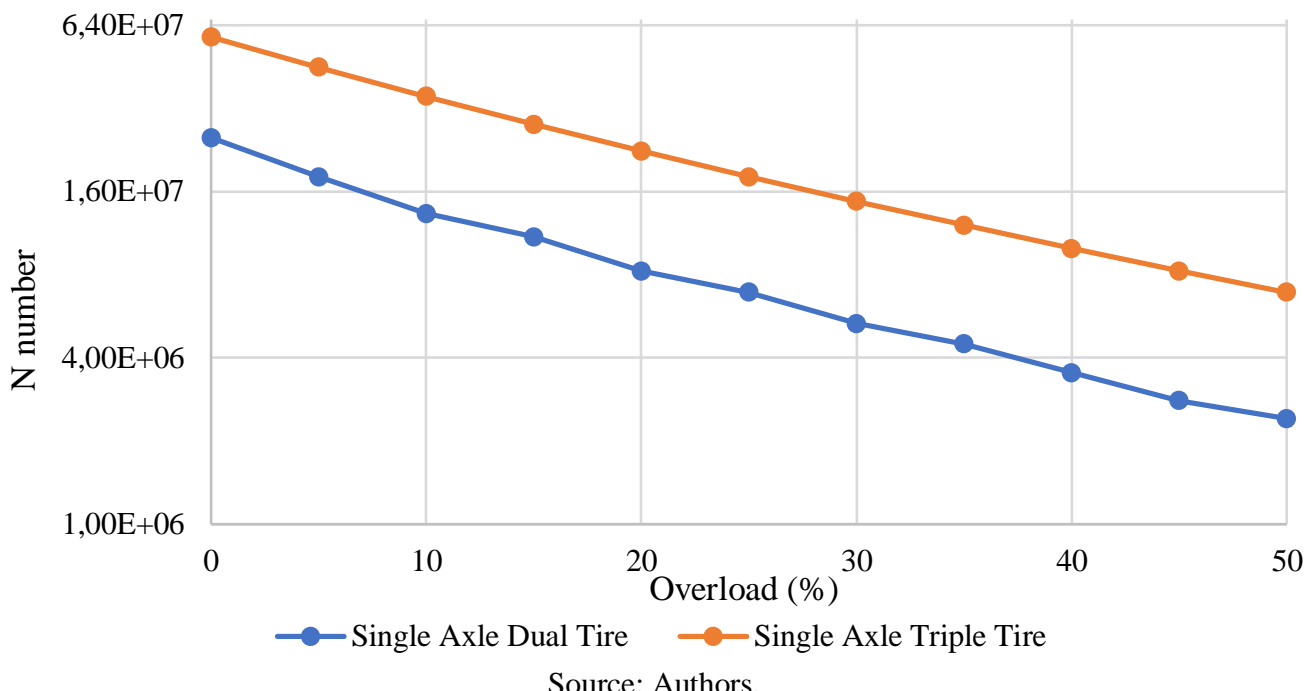

\section{Discussion}

In this research, some factors were considered that led to the relevance of the results. In Brazil, road transport represents more than $70 \%$ of the total vehicle and becomes the most important means of supply and cargo movement in the country. Taking an economic view, we see the need to reduce costs, both in the maintenance and conservation of highways and in the value of freight itself. The study verified the importance of resultant tensions applied in the pavement through the loads imposed by the commercial vehicles' weight.

Dey et al. (2014) mention that for trucks with loads above the legal weight limits, DOTs issue special licenses. With specific control of the scale load, the maintenance processes of bridges and pavements can drop significantly and would require less frequent maintenance and rehabilitation. Transport control policies and alternative ways have been looking more efficiently for revenue sources to maintain the infrastructure. Because of the damage caused by overweight trucks and recover the costs of the accelerated deterioration, it is necessary to quantify the damage to bridges and pavements attributed to overweight trucks. 
Based on the damage estimate, damage costs for overweight trucks are estimated for the most common recovery fee typesadditional damage costs above the legal limit up to the maximum overweight limit.

Pais et al. (2013) present a study on the impact of overloaded vehicles on road pavements' performance, studying the truck factor for different vehicle types when applied to a set of pavements, including five different asphalt layers thicknesses and five other subgrade stiffness modules. The presented results allowed us to conclude that heavy vehicles do not operate with the maximum load defined by law. On average, and depending on the shaft's position, each axle varies from 20 to $90 \%$ of the full legal load. However, for classes F4 and H6, the number of cars overloaded varied from 40-60\%. The presence of overloaded vehicles can increase costs by more than $100 \%$ compared to the same cars' price with legal loads.

Different distribution patterns were observed between overweight and unweighted traffic in truck classes and axle load spectra (Wang et al., 2015). The reduction in pavement life was used to normalize the effect of an overweight truck in different conditions. In general, it shows that a $1 \%$ increase in overweight trucks can cause a $1.8 \%$ reduction in pavement life. The M-E analysis proved to be a valid approach to quantify the impact of overweight trucks on pavement damage at the network level by comparing the expected pavement life from the M-E analysis and field-estimated performance data.

Another study using SAFEM (Finite Elements) for predicting the asphalt pavement structural responses under static loads (Liu et al., 2015) proposes the use of MATLAB-based software. A comparison with ABAQUS verified the accuracy of the program. Pavement responses to a static load predicted by SAFEM and ABAQUS are in excellent agreement. Furthermore, the computational time of the SAFEM is much shorter than that of the ABAQUS. To further reduce the computational time, the infinite elements are coupled with the finite elements in the SAFEM. As a result, the pavement model's scale at the infinite domain controlled a suitable level, and computational time reduced without decreasing its accuracy.

For further investigation, the SAFEM allows dynamic analysis and various material properties, such as viscoelasticity for asphalt and nonlinear elasticity, for the pavement subbase. Furthermore, the regulation of the minimum amount of the finite elements required to use in the finite-infinite element coupling analysis should be determined by the theoretical research and large numbers of case studies.

The world economic scenario demands increasingly require cost optimization and technical adequacy to achieve better results, aiming at a surplus in the cost/profit ratio of the trade balance. There was a need to reinvent mechanisms already considered established in the market and studies for more favorable adaptations to new demands in this context. In the commercial vehicle, the market found a structure that has been used for cargo transport for years. It was verified the possibility of a new study of load distribution on the pavement through the pressure exerted by tires, which, by extension, would benefit the amount of cargo to be transported by the same truck in the same freight generating the same damage on the pavement of the typical structure used in the current standard of balance load.

The viscoplastic stress is located at the bottom of the asphalt concrete layer when the BGS layer is not compacted. The region location moves to the middle of the asphalt concrete when the BGS layer is rigid. These simulations revealed that the structure of steel-concrete layers depends heavily on the properties of the BGS layer. The configuration of the stress contact. Therefore, future studies will focus on how the asphaltic concrete layer's regular performance is altered by the variation of Graded Gravel and subgrade layer properties.

\section{Conclusions}

The following conclusions can be drawn from the simulations in the present study:

- Groove depth in the asphalt concrete layer under everyday realistic contact stresses is about 1.5 times greater than the groove's center under standard pressure evenly distributed.

- The distribution of stress should depend on the transverse location with its maximum in the center transverse direction of the 
contact area to ensure the groove's maximum depth in the contact area's center.

- The magnitude of the routine depth in the asphaltic concrete layer is usually inversely proportional to the stiffness of the BGS Layer.

The implementation of a standardized tire and already established double axle, forming a triple tire, proved to be quite efficient in two main points, (1) in the technical scope, it generates an increase in the permissible load to be transported on the triple axle, generating the same damage as standard double axle; and (2) in the economic view, we will have a greater load capacity at the same freight value.

For further study, we suggest an economic survey on freight cargo and fuel consumption in the real scenario of cargo transportation on Brazilian highways to check the impact of the proposed changes on the environment.

\section{References}

AASHTO. (1972). Guide for design of pavement structures. American Association of State Highway and Transportation Officials, Washington, D.C. USA.1972. AASHTO. (1993). Guide for design of pavement structures. American Association of State Highway and Transportation Officials, Washington, D.C, USA.

Bartholomeu, D. B. (2006). Quantificação dos impactos econômicos e ambientais decorrentes do estado de conservação das rodovias brasileiras. Tese (Doutorado) - Universidade de São Paulo, Escola Superior de Agricultura Luiz de Queiroz, Piracicaba.

BNDES - Banco Nacional de Desenvolvimento Econômico e <http://www.bndes.gov.br/SiteBNDES/bndes/bndes_pt/Areas_de_Atuacao/Infraestrutura/Logistica/index.html>.

CNT - Confederação Nacional dos Transportes (2020). <http://www.cnt.org.br/Paginas/Boletins.aspx>.

DER - São Paulo -Brasil. (2006). Departamento de Estradas de Rodagem do Estado de São Paulo. Instituto de Pesquisas Rodoviárias. Instrução de Projeto de Pavimentação, IP-DE-P00-001_A.

DNER - Avaliação Estrutural de Pavimentos Flexíveis. (1979). DNER-PRO11/79. Departamento Nacional de Estradas e Rodagens, Rio de Janeiro.

DNER Manual de reabilitação de pavimentos asfálticos. (1998). Departamento Nacional de Estradas de Rodagem, Rio de Janeiro.

DNIT - BrasiL. (2006). Ministério dos Transportes. Departamento Nacional de Infraestrutura de Transportes. Diretoria de Planejamento e Pesquisa. Ins tituto de Pesquisas Rodoviárias. Manual de Pavimentação, (3a ed.).

Dormon, G. M., \& Metcalf, C. T. (1965). Design Curves for Flexible Pavements Based on Layered System Theory. Highway Record 71. Highway Research Board, Washington DC.

Wang, H., Zhao, J., \& Wang, Z. (2015). Impact of Overweight Traffic on Pavement Life Using Weigh-In-Motion Data and Mechanistic-Empirical Pavement Analysis. $9^{\text {th }}$ International Conference on Managing Pavement Assets (ICMPA9) in Alexandria, VA,USA.

IPEA - Instituto de Pesquisa Econômica Aplicada. (2020). < http://www.ipea.gov.br/portal/index.php?option=com_alphacon tent\&view=alphacontent\&Itemid=357\&search=transporte+rodoviario $>$.

Dey, K. C., Chowdhury, M., Pang, W., Putman, B. J., \& Chen, L. (2014). Estimation of Pavement and Bridge Damage Costs Caused by Overweight Trucks. Journal of the Transportation Research Board. 2411, 62-71.

Kim, S., Darab, M. K., Little, D. N., \& Al-Rub, R. K. A. (2018). Effect of the Realistic Tire contact Pressure on the Rutting Performance of Asphaltic Concrete Pavements. KSCE Journal of Civil Engineering, 22 (6), 2138-2146.

Lin, S, Ashlock, J. C., \& Williams, R. C. (2016). Nondestructive quality assessment of asphalt pavements based on dynamic modulus. Construction and Building Materials 112, 836-847.

Liu, P., Wang, W., \& Oeser, M. (2015). Application of semi-analytical finite element method coupled with finite element for analysis of asphalt pavement structural response. Journal of Traffic and Transportation Engineering 2(1), 48- 58.

Medina, J., \& Motta, L. M. G. (1989). Resilient behavior of Brazilian tropical soils in pavement design. International Symposium On Pavement Evaluation and Overlay Design, 2, Rio de Janeiro. Proceedings... Rio de Janeiro: ABPv 1, 1-22.

Pais, J. C., Amorim, S. I. R.; \& Minhoto, M. J. C. (2013). Impact of Traffic Overload on Road Pavement Performance. Journal of Transportation Engineering, $139,873-879$

Pais, J. C., Figueiras, H., Pereira, P., \& Kaloush, K. (2019). The pavements cost due to traffic overloads. International Journal of Pavement Engineering 20 (12), 1463-73.

Pereira, A. S., Shitsuka, D. M., Parreira, F. J., \& Shitsuka, R. (2018). Metodologia da pesquisa científica. UAB/NTE/UFSM. <https://repositorio.ufsm.br/bitstream/handle/1/15824/Lic_Computacao_Metodologia-Pesquisa-Cientifica.pdf?sequence=1 >.

Santana, H. (1993). Manual de Pré-Misturados a Frio. IBP/ Comissão de Asfalto. Rio de Janeiro, RJ. 
Research, Society and Development, v. 10, n. 1, e39710111852, 2021

(CC BY 4.0) | ISSN 2525-3409 | DOI: http://dx.doi.org/10.33448/rsd-v10i1.11852

Shell International Petroleum Company, Ltd. (1978). Shell Pavement Design Manual: Asphalt Pavements and Overlays for Road Traffic. Shell International Petroleum Company, Ltd, London.

Souza, M. L. (1981). Método de projeto de pavimentos flexíveis.DNER. 